\title{
THE EFFECT OF ORGANIZATIONAL CITIZENSHIP BEHAVIOR ON JOB SATISFACTION MEDIATED WITH SPIRITUAL LEADERSHIP
}

\author{
Achmad Sani Supriyanto* \\ State Islamic University of Maulana Malik Ibrahim \\ Vivin Maharani Ekowati \\ State Islamic University of Maulana Malik Ibrahim
}

Abd. Haris

State Islamic University of Maulana Malik Ibrahim

Budi Eko Soetjipto

State University of Malang

Rudi Harianto

State Institute for Islamic Studies of Madura

Muchlis Yahya

State Islamic University of Walisongo Semarang

\begin{abstract}
This study aims to determine the direct effect of Organizational Citizenship Behavior on job satisfaction mediated with spiritual leadership. Data were randomly selected from 115 employees of Bank Jatim Syariah in the central office, Surabaya, and analyzed using the Partial Least Square. The study shows that Organizational Citizenship Behavior has a direct effect on job satisfaction with spiritual leadership. The practice of OCB has the ability to shape the subordinate mindset to be always responsible for their work. Organizational citizenship behavior underlies the leadership pattern to commit to workload.
\end{abstract}

Keywords: Organizational citizenship behavior; Spiritual leadership; Job satisfaction.

Received: 27 November 2019

Accepted: 20 May 2020

\section{INTRODUCTION}

Humans are the most important resources of a company due to their unique nature, therefore, it is important to improve their quality. An important indicator for determining the quality of human resources is a good performance, and this is applicable to banks, one of which is Bank Jatim Syariah. The national banking sector faces more challenges due to its integration in the ASEAN

\footnotetext{
* Corresponding Author: Faculty of Economics, State Islamic University Of Maulana Malik Ibrahim, Indonesia. Phone: 08125959 1172. E-mail: achmad_sani72@yahoo.com.
} 
Economic Community (AEC) in 2020 and the rapid development of technology that requires innovation and more flexible services. The banking sector needs to improve the technology, business, human resources, and infrastructure, in order to avoid major losses and anticipate the impact of the AEC (Sani \& Ekowati, 2019).

Effective human resource management is the key to improving work performance. Robbins (2006) stated that OCB and leadership satisfaction are some of the several factors that influence job satisfaction. Therefore, the Bank of Jatim Syariah needs to consider these factors before developing its human resource management program. Recently, companies have spent millions of dollars on developing their employees, which, shows that attitudes and performance are key to achieving the estimated goals (Sani \& Ekowati, 2019).

The leadership practice keeps growing and has the ability to develop into spirituality, which is one of the new dimensions for leaders in the future. According to Yusof \& Tahir (2011), spiritual leadership includes teaching followers true principles and applying techniques that enable selfgovernment. Spiritual leadership supports employees to fulfill the future needs of an organization by generating trust while focusing on the value of altruistic love and vision incorporated into its culture. Leaders' attitudes and behaviors express altruistic love for their employees, which in turn provides them a sense of organizational ownership (Bodla, Ali, \& Danish, 2013). Spiritual leadership, as a model for organizational development and transformation, leads to the evolution of positive organizations where human welfare and organizational-level performance coexist and are optimized (Yusof \& Tahir, 2011).

An organization is unable to run properly without the members engaging in positive behavior due to OCB. According to Stamper \& Dyne (2001), OCB is a part oforganizational culture with direct and indirect affects on employee characteristics. It is also a key used to support organizational sustainability, and increase effectiveness and efficiency. Faizal, Mathew \& James (2015), stated that Total Quality Management (TQM) increases competitive advantage and affects performance. The relationship between total quality management and performance in business creates an effective and competent organization.

Podsakoff, Whiting, Podsakoff, \& Blume (2009) also stated that citizenship behaviors in organizations enhance individual and organizational effectiveness. The increasing importance has led scholars to recognize helping behavior as one of the core components of job performance, which is a critical manifestation of ethical behavior ((Ahmed, Arshad, Mahmood, \& Akhtar (2019); DeClercq, Rahman, \& Haq (2017)).

Researchers are concerned with the use of OCB as a potential to improve organizational efficiency by increasing employee performance and productivity (Podsakoff, MacKenzie, Paine, and Bacharach (2000), and Kasa \& Hassan (2017)). Previous studies stated that there is a close relationship between job satisfaction and OCB ((Organ, Podsakoff \& MacKenzie (2006), (Salehi \& Goltash (2011)), and (Banahene, Eric, \& Abigail, 2017). Organ, Podsakoff \& MacKenzie (2006) stated that employers voluntarily help new employees to become more productive to increase efficiency.

Some studies show that leadership positively affects human behavior, such as employee satisfaction and commitment (Boon, Bakar, Arumugam, Vellapan, \& Loke, 2007) and Adawiyah, Shariff, Saud, \& Mokhar (2011). Kabak, Sen, Goçer, Kuçuksoylemez, \& Tuncer (2014) further 
stated that employee training, education, relationships, teamwork, appreciation, recognition, cultural quality, and employee empowerment positively affect job satisfaction. Bari, Fanchen, \& Baloch (2016) show that leadership, teamwork, and customer focus affect job satisfaction, while organizational culture does not.

Employees act as an important component to overcome organizational challenges. According to Berman (2006), performance is effectively and efficiently used to achieve the defined results in organizations. OCB plays an important role in increasing employee job satisfaction. It stimulates practitioners and academics to look for new important construction (Mallick, Rabindra, Hare, \& Lalatendu, 2015), and (Sani, Ekowati, Wekke, \& Idris, 2018).

Considering the crucial role of OCB in improving the quality of an organization, this study aims to examine the influence of OCB to the job satisfaction, the role of spiritual leadership mediating OCB toward job satisfaction.

\section{LITERATURE REVIEW}

OCB is contextualized as performance or behavior manifested in the psychological and social environment to improve and support tasks. This behavior serves to support task performance that benefits organizations manifested in conscious and voluntary willingness to work (Organ, Podsakoff, \& MacKenzie, 2006).

OCB involves several behaviors, such as helping people, becoming volunteers for extra tasks, and obeying the procedures in the workplace. This behavior describes the added value of employees and a form of prosocial behavior, positive, constructive, and meaningful behavior in the workplace in accordance with the personal judgment that exceeds one's work requirements. Podsakoff et al. (2000) stated that organizational theory, following a cooperation system, and people's willingness to contribute and strive in a cooperation system is an absolute requirement for an organization. Job Satisfaction with the Islamic perspective is the peace gained before, during, and after work based on the belief that worship may stimulate to achieve the pleasure of Allah SWT (Saadiah, Mohamad, \& Hayaati, 2014). The peace before, during, and after work is an intention to be devoted to Allah SWT, avoid violating Shari'a, and indirectly gained the assumption to worship. The Islamic Job Satisfaction variable is based on the element of human creation from Holy Qur'an by referring to the interpretation by al-Ghazali, that there are four dimensions for human beings namely peace, soul (ruhiyyah), intellectual ('aqliyyah), social (nafsiyyah) and material (jasadiyyah).

Banahene, Eric, \& Abigail (2017) stated that there is a close relationship between OCB and job satisfaction. Robbins \& Timothy (2011) reported that leadership supervision is one of the factors that influence job satisfaction in an organization. Based on previous researches and theoretical studies, the following hypothesis was formulated.

H1. OCB directly affects the job satisfaction

Spiritualist-based leaders play an important role in realizing spiritual values in an organization. Four key practices are used to create a strong spiritual leadership personality, namely (1) knowing self, (2) respecting others' beliefs (3) trusting, and (4) maintaining spiritual practice performing 
belief and guidance of each religion as prayer, meditation, yoga, etc. Padayachee (2009) stated that leaders effectively implement practices to nurture and respect the spiritual needs of employees. However, this creates unhealthy consequences for individuals, organizations, and society. Furthermore, good leaders need to integrate spirituality with five leadership practices, to challenge the process, inspire a shared vision, enable others to act, and encourage the heart. (Wijayanti \& Wajdi, 2012) also argued that Islamic leadership has a significant effect on job satisfaction. According to Boon et al. (2007) and Bari, Fanchen, \& Baloch (2016), leadership positively affects employee satisfaction.

Jung \& Hong (2008) stated that there is a relationship between OCB and leadership, which positively affects the performance mediated by soft TQM. Faizal, Mathew \& James (2015) stated that conscientiousness and courtesy affect leadership, with no effect on the other three dimensions. Therefore, the following hypothesis was formulated.

H2: Spiritual Leadership mediates the effect of OCB on job satisfaction.

\section{Hypothesis Model}

Figure 1: The Effect of Organizational Citizenship Behavior,spiritual leadership on job satisfaction

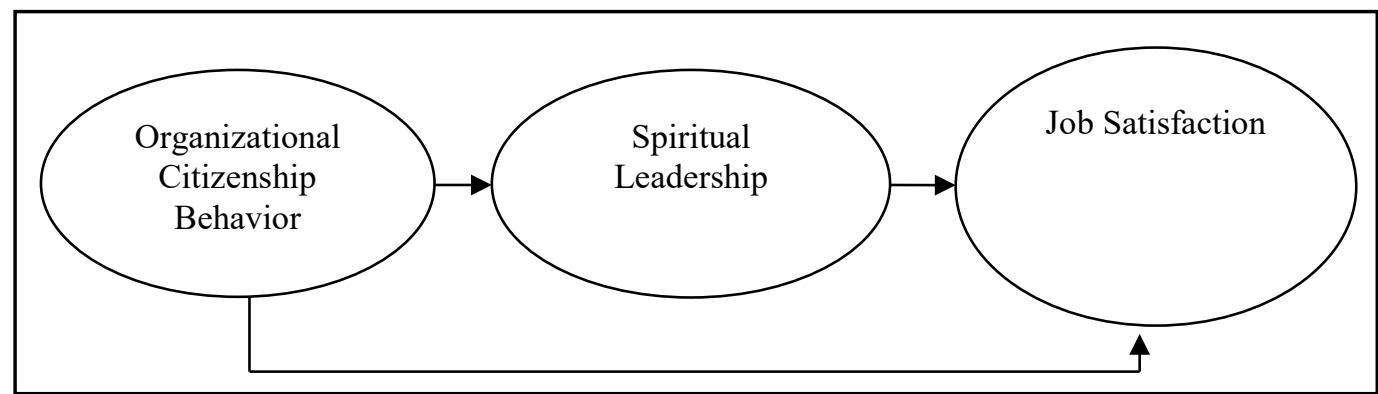

\section{METHODOLOGY}

Data were obtained from a total of 160 full-time employees of Bank Jatim Syariah in the Center Office of Surabaya. Proportional random sampling technique using Slovin formula is used.Furthermore, using a 5 percent confidence level, the total samples were 115 employees, including supervisors.

$$
\begin{aligned}
& \mathrm{n}=\frac{\mathrm{N}}{\mathrm{N}(\mathrm{d})^{2}+1} \\
& \mathrm{n}=\frac{160}{160(0.05)^{2}+1}
\end{aligned}
$$




\section{Description :}

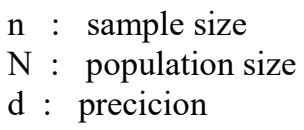

The five-point Likert was used to survey the questionnaire, comprising of strongly disagree to strongly agree. OCB was measured through 5 indicators adopted from researches carried out by Ekowati, Surachman, Sumiati, \& Sudiro (2017) and Podsakoff, Ahearne, \& MacKenzie (2006), namely altruism, civic virtue, conscientiousness,sportsmanship, and courtesy. Job satisfaction was measured using four indicators adopted from the research carried out by Saadiah, Mohamad, \& Hayaati (2014), namely moral, material, social, and intellectual satisfaction. Yusof and Tahir (2011) stated that spiritual leadership is measured through 5 indicators, namelyvision, hope, altruistic love, meaning, and membership.

Descriptive statistical analysis is used to determine the frequency distribution of respondents' answers from a questionnaire and provide an in-depth analysis of the studied variables. Data were analyzed with Partial Least Square (PLS), which is characterized as a technique suitable where the research purpose is a prediction or exploratory modeling. PLS is favored as a predictive technique and recommended at the early stage of theoretical development to test and validate exploratory models (Garson, 2016). According to Ghozali (2016), testing mediation hypothesis is conducted by a procedure developed by Sobel Test, which is used to influence organizational citizenship behavior on job satisfaction through spiritual leadership. The mediation of the examination employs the procedure developed by Sobel with software Free Statistic Calculation for Sobel version 4.0 .

\section{RESULTS AND DISCUSSION}

Analysis in relation to the characteristic of information was conducted, with 61 percent are male and 39 percent female respondents. In accordance with the unit, 11 and 24 percent are front and back officers, while 65 percent are marketers. Regarding experience, 37 percent have less than 5 years, 50 percent have 5-10-years, while 13 percent have been working for more than 10 years. The characteristic of the respondent analysis is shown in Table 1.

Table 1: Respondents Characteristic

\begin{tabular}{|c|c|c|}
\hline "DemographicVariable & $\overline{\mathbf{N}}$ & Percentage \\
\hline \multicolumn{3}{|l|}{ Gender } \\
\hline Male & 70 & 61.0 \\
\hline Female & 45 & 39.0 \\
\hline \multicolumn{3}{|l|}{ Unit } \\
\hline Front Office & 12 & 11.0 \\
\hline Back Office & 28 & 24.0 \\
\hline Marketing & 75 & 65.0 \\
\hline
\end{tabular}




\begin{tabular}{ccc}
\hline \hline DemographicVariable & N & Percentage \\
\hline Experience (in years) & & \\
$<05$ & 42 & 37.0 \\
$05<10$ & 58 & 50.0 \\
10 and above & 15 & 13.0 \\
\hline \hline
\end{tabular}

Table 2: Results of The Reliability

\begin{tabular}{ccc}
\hline \hline Variable & Cronbach's $\boldsymbol{\alpha}$ & Conclusion \\
\hline Job Satisfaction & 0.699 & Reliable \\
OCB & 0.667 & Reliable \\
Spiritual Leadership & 0.784 & Reliable \\
\hline \hline
\end{tabular}

Table 2, shows that the reliability examination and $\alpha$ coefficient is obtained for job satisfaction, with $\mathrm{OCB}$, and spiritual leadership variables above 0.6. This value shows that the research instrument is reliable.

Test the structural equation of the PLS approach. Discriminant validity uses the square root of the average extracted $(\sqrt{A V E})$. If the $\sqrt{ } \mathrm{AVE}$ value of each latent variable is greater than the correlation with other variables, then the instrument is said to have good discriminant validity (Solimun \& Fernandes, 2017). The recommended measurement value must be greater than 0.5 . The results of calculating the $\mathrm{AVE}$ value, as shown in Table 3 . Thus the instrument is said to be valid because the AVE value is greater than 0.5 .

Table 3: $\sqrt{ }$ AVE Values, AVE, and Correlations Between Latent Variables

\begin{tabular}{|c|c|c|c|c|c|}
\hline \multirow[b]{2}{*}{$\begin{array}{l}\text { Research } \\
\text { Variable }\end{array}$} & \multirow[b]{2}{*}{ AVE } & \multirow[b]{2}{*}{$\sqrt{ } \mathbf{A V E}$} & \multicolumn{3}{|c|}{ Correlations of the latent variables } \\
\hline & & & $\begin{array}{c}\text { Job } \\
\text { Satisfaction }\end{array}$ & OCB & $\begin{array}{c}\text { Spiritual } \\
\text { Leadership }\end{array}$ \\
\hline Job Satisfaction & 0.539 & 0.734 & 1.0000 & & \\
\hline OCB & 0.592 & 0.769 & 0.256 & 1.0000 & \\
\hline $\begin{array}{l}\text { Spiritual } \\
\text { Leadership }\end{array}$ & 0.941 & 0.970 & 0.227 & 0.436 & 1.0000 \\
\hline
\end{tabular}

Table 4: Results of the reliability

\begin{tabular}{lcl}
\hline \multicolumn{1}{c}{ Variable } & $\begin{array}{c}\text { Composite } \\
\text { reliability }\end{array}$ & Result \\
\hline Job Satisfaction & 0.755 & Reliable \\
OCB & 0.752 & Reliable \\
Spiritual Leadership & 0.888 & Reliable \\
\hline \hline
\end{tabular}

The composite reliability values were used to shape the construct with the results in the good, assuming the value is above 0.70 . The test results of the composite reliability measurement model are shown in Table 4with job satisfaction, OCB, and Spiritual leadership variables of 0.755, 0.752, and 0.888 . This means that the three variables analyzed have good composite reliability because 
the value is above 0.70 . Therefore, further analysis needs to be conducted by examining the goodness-of-fit and inner models.

The goodness-of-fit test of the structural model used the predictive relevance (Q2) score to measure how observation scores are generated. Q2 was based on the coefficient of determination of all the dependent variables between $0<\mathrm{Q} 2<1$. The $\mathrm{R}^{2}$ value of each endogenous variables are follows: a) Y1 variable has $\mathrm{R}^{2}$ of 0.390 ; b) $\mathrm{Y} 2$ variable has $\mathrm{R}^{2}$ of 0.396 ; and $\mathrm{Y} 3$ variable has $\mathrm{R}^{2}$ of 0.582

Predictive-relevance value is obtained by formulation below:

$\mathrm{Q}^{2}=1-\left(1-\mathrm{R}_{1}^{2}\right)\left(1-\mathrm{R}_{2}^{2}\right) \ldots\left(1-\mathrm{R}_{\mathrm{p}}^{2}\right)$

$\mathrm{Q}^{2}=1-(1-0.390)(1-0.582)$

$\mathrm{Q}^{2}=0.745$

The analysis showed that Q2 was 0.745 or 74.5 percent, which showed that the model was able to explain 74.50 percent of the data, while the remaining 25.5 percent was explained by other variables (outside the model) and error. In conclusion, based on the analysis, the PLS model was good due to its ability to explain 74.50 percent of the overall information.

\section{Hypothesis Testing Results (Inner Model)}

Table 5: The Direct Effects of Research Variables

\begin{tabular}{lccccc}
\hline \hline & Relationship & $\begin{array}{c}\text { Path } \\
\text { Coefficients }\end{array}$ & $\begin{array}{c}\text { t- } \\
\text { value }\end{array}$ & p-value & Decision \\
\hline OCB & $\begin{array}{c}\text { Job satisfaction } \\
\text { Spiritual }\end{array}$ & 0.194 & 2.409 & 0.017 & Significant \\
OCB & $\begin{array}{c}\text { leadership } \\
\begin{array}{l}\text { Spiritual } \\
\text { leadership }\end{array}\end{array}$ & 0.436 & 9.772 & 0.000 & Significant \\
\hline \hline
\end{tabular}


Figure 3: Path Diagram of Structural Model in PLS

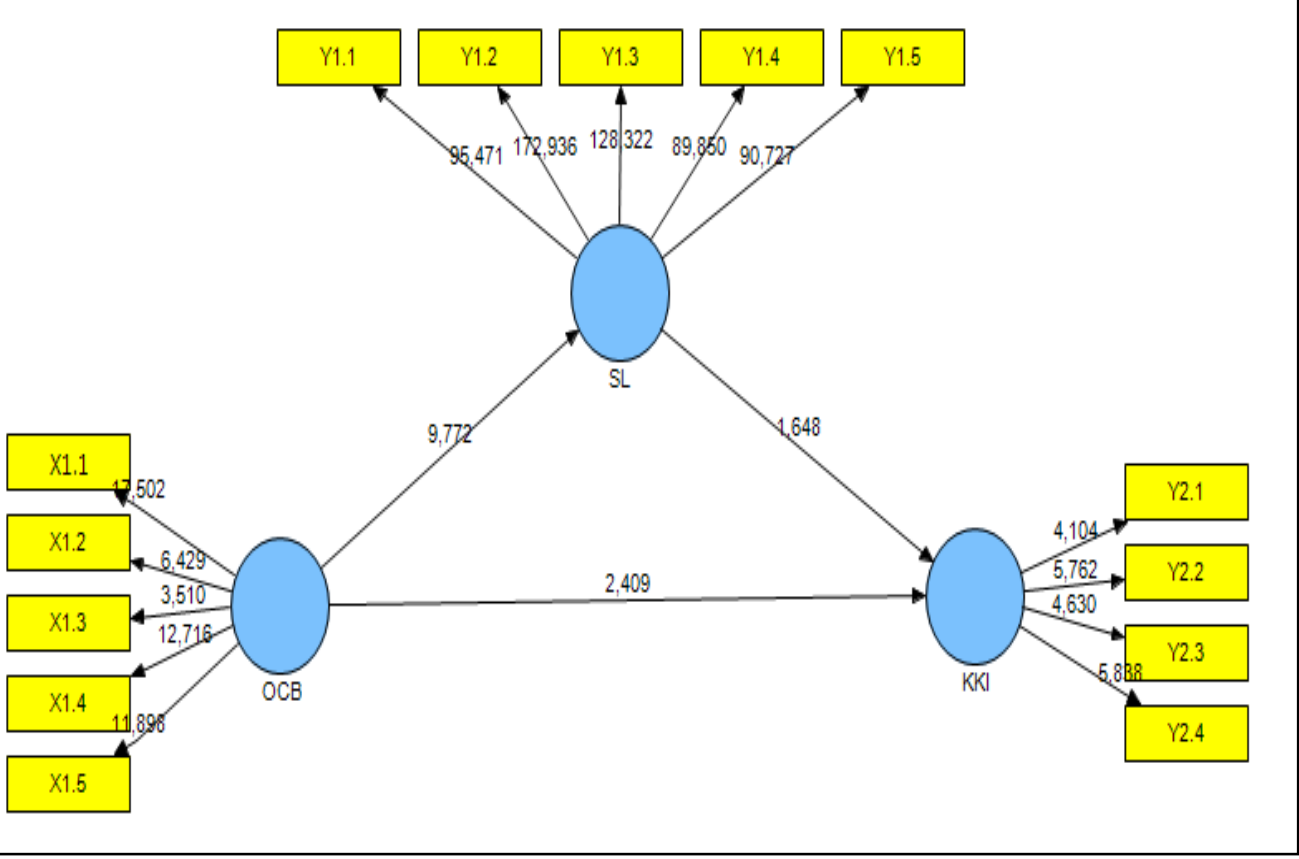

Description :

OCB (X1) : Organizational citizenship behavior

SL (Y1) : Spiritual Leadership

KKI (Y2) : Job Satisfaction

Hypothesis testing mediation is needed to detect the position of the intervening variable in the model. It is conducted through Sobel test studies on the effect of OCB on job satisfaction through spiritual leadership using the testing calculator, version 4.0, as shown in table 6 .

Table 6: Sobel Test Results

\begin{tabular}{lccccccc}
\hline \hline Path & $\mathbf{A}$ & $\mathbf{B}$ & $\mathbf{S E}_{\mathbf{A}}$ & $\mathbf{S E}_{\mathbf{B}}$ & t count & Sig. & Description \\
\hline OCB-SL-KKI & 0.436 & 0.142 & 0.058 & 0.115 & 1.218 & 0.223 & Insignificant \\
\hline \hline
\end{tabular}

Table 6 shows that the Sobel Test value is $1.218<1.96$ with significance values of $0.223>0.05$. The fact that $\mathrm{t}$-count $<\mathrm{t}$ table and sig. $>0.05$ means spiritual leadership is not a mediation variable for the effect of OCB on job satisfaction.

Banahene, Eric, \& Abigail (2017) stated that the inner model of path analysis has a significant effect on job satisfaction. Therefore, OCB increases job satisfaction, which leads to a rise in employee loyalty. The result of the study is consistent with De Clercq, Rahman, \& Haq (2017) and Ahmed et al. (2019) reported that helping behavior as one of the core components of job satisfaction. The result of the study is inconsistent with Organ, Podsakoff, and MacKenzie (2006), 
which reported that satisfied employees commonly make more contributions (OCB) with a satisfied stronger tendency to carryout OCB because it creates a reciprocal norm of psychological contract (Carol,Carol \& Rachel, 2003).

The finding of the current research goes against the opinion of Robbins \& Timothy (2011) which satisfied employees' ability to positively impression the organization, help colleagues, and exceed the normal estimation of performance. Moreover, they tend to be more obedient to their jobs because they want to repeat their positive experiences. This research is inconsistent with the study carried out by Salehi \& Goltash (2011), which stated there is a positive relationship between job satisfaction and OCB. However, it is in line with the study by Luthans (2011), which stated that job satisfaction is the result of employee perceptions on how someone carried out important activities related to their work.

Someone has the potential to make OCB due to social exchange concepts and psychological contracts. The social exchange concept is a voluntary action from individuals driven by the expectation of profit as a mixture of intrinsic and extrinsic satisfaction. A worker involving in social exchanges has an obligation to repay the benefits voluntarily given to others. However, the obligation on when the remuneration needs to be returned is never clearly determined (Organ, Podsakoff, and MacKenzie, 2006; Podsakoff et al., 2000). The study shows that employees in a competitive atmosphere are encouraged to work optimally to complete their tasks and responsibilities in order to meet the targets and plans. A positive competition among employees in the workplace stimulates them to show their abilities and potential, thereby making them aware of the company goals.

The inner model of path analysis shows that OCB has a significant effect on spiritual leadership. Jung \& Hong (2008) stated that OCB has a positive effect on leadership with the ability to strengthen the implementation of soft TQM. OCB is one of the factors capable of predicting the quality of management within leadership. However, the results of the current research in not in accordance with the study conducted by Faizal, Mathew \& James (2015), regarding the effect of OCB on soft TQM. Furthermore, Ugboro and Obeng (2000) stated leadership from the top management is realized with a vision capability to direct subordinates to improve performance. The practice of OCB tends to shape the mindset of the subordinates to be responsible for the workload.

The inner model of path analysis shows that spiritual leadership has no significant effect on job satisfaction. This is in line with the research carried out by Saleem (2015), which stated that leadership has an indirect effect on job satisfaction through organizational politics. Sani, Soetjipto, \& Maharani (2016) stated that spiritual leadership does not affect job satisfaction, which can affect the motivation of employees' intellectual, job satisfaction, and acquire new knowledge. Job satisfaction is in the form of Jasadiyah (salary) inner satisfaction, aqliyah (addition of knowledge), and social satisfaction. The motivation of Muslims is based on physical interest and spiritual needs(ruhiyah). Leadership does not affect satisfaction, which is acquired before, during, and after work, to achieve the pleasure of Allah SWT (Saadiah, Mohamad, \& Hayaati, 2014).

The mediation model shows that spiritual leadership is not a variable of OCB effect on job satisfaction. Spiritual leadership plays an essential role in realizing the four key practices in an organization. These include (1) knowing self, (2) respecting others' belief (3) giving trust, and (4) 
maintaining a spiritual practice-doing the religious tenets and guidance, meditation, yoga, etc (Padayachee, 2009).

\section{CONCLUSION}

In conclusion, OCB has a direct effect on job satisfaction due to social exchange concepts and psychological contracts. The social exchange concept is a voluntary action from individuals driven by profit expectations. This includes a mixture of intrinsic and extrinsic satisfaction and the benefits obtained from others.

Spiritual leadership failed to mediate the effect of OCB on job satisfaction. The practices implemented by leaders tend to shape the mindset of the employees to be responsible for their work. OCB underlies the pattern of leadership to be mandated in conducting their work. Spiritual leadership does not have the ability to increase job satisfaction, which is stimulated by Jasadiyah (salary), aqliyah (additional knowledge), and social satisfactions. When employees are dissatisfied with leadership, it causes a decrease in a job.

The research results suggest several factors capable of increasing job satisfaction, such as OCB and leadership. A leader needs to improve the job satisfaction of employees to ensure their spiritual values in daily activities. The application needs to be supported by both leaders and employees using the right policies. Future studies need to carried out on the development of spiritual, intelligent variable as a mediation.

\section{REFERENCES}

Adawiyah, W. R., Shariff, M. N. M., Saud, M. B., \& Mokhar, S. S. (2011). Workplace spirituality as a moderator in the relationship between soft TQM and organizational commitment. International Journal of Business and Social Science, 2(10), 93-100.

Ahmed, M., Arshad, A., Mahmood, A., \& Akhtar, S. (2019). The influence of spiritual values on employee's helping behavior: the moderating role of Islamic work ethic. Journal of Management, Spirituality \& Religion, 16(3), 1-29.

Banahene, S., Eric, A., \& Abigail, A. (2017). The measurement of organizational citizenship behaviour and its impact on job satisfaction and loyalty among christian workers in Ghana. International Journal of Business Marketing and Management (IJBMM, 2(5), 2033.

Bari, M. W., Fanchen, M., \& Baloch, M. A. (2016). TQM soft practices and job satisfaction: Mediating role of relational psychological contract. Procedía - Social and Behavioral Sciences, 235(2016), 453-462.

Berman, E. M. (2006). Performance and productivity in public and nonprofit organizations (2nd ed. Ar). N.Y: M.E.

Bodla, M. A., Ali, H., \& Danish, R. Q. (2013). Role of spiritual leaders in enhancing employee's performance. Journal of Basic And Applied Scientific Research, 3(3), 117-122. 
Boon, K. O., Bakar, N. A., Arumugam, V., Vellapan, L., \& Loke, A. K. Y. (2007). Does TQM influence employees' job satisfaction? An empirical case analysis. International Journal of Quality and Reliability Management, 24(1), 62-77.

Carol, C. B., Carol, W. D \& Rachel, K. S. (2003). Organizational citizenship behavior and service quality. Journal Of Services Marketing, 17(4), 357-378.

DeClercq, D., Rahman, Z., \& Haq, U.I. (2017). Explaining helping behavior in the workplace: the interactive effect of Family-to-work conflict and Islamic work ethic. Journal of Business Ethics, 142(1), 1-11.

Ekowati, V. M., Surachman, Sumiati, \& Sudiro, A. (2017). The effect of transformational leadership on organizational citizenship behavior mediated by job satisfaction and organizational commitment (study at Islamic Bank in Malang Raya). International Journal of Economic Research, 14(3), 205-218.

Faizal, M., Mathew, A., \& James, M. J. (2015). A case study on the impact of organizatioanl citizenship behavior on total quality management In an Indian public sector electrical manufacturing subsidiary. Journal of Asian Business Strategy, 5(10), 215-226.

Garson, G. D. (2016). Partial least square: Regression and structural equations models. North Carolina State University, USA: School of public \& international affairs. Retrieved from https://www.smartpls.com/resources/ebook_on_pls-sem.pdf.

Ghozali, I. (2016). Multivariate analysis application with the IBM SPSS 23. Semarang: Diponegoro University Publisher Agency.

Jung, J. Y., \& Hong, S. (2008). Organizational citizenship behaviour (OCB), TQM and performance at the Maquiladora. International Journal Of Quality and Reliability Management, 25(8), 793-808.

Kabak, K., Sen, A., Goçer, K., Kuçuksoylemez, S., \& Tuncer, G. (2014). Strategies for employee job satisfaction: A case of service sector. Procedia - Social and Behavioral Sciences, 150 (2014), 1167-1176.

Kasa, M., \& Hassan, Z. (2017). The relationship of burnout dimensions with organizational citizenship behavior (OCB) among bank employee in Serawak: mediating role of flow experience. International Journal of Business and Society, 18(4), 685-691.

Luthans, F. (2011). Organizational behavior. An evidence-based approach. (12 ${ }^{\text {th }}$ ed.). New York: McGraw - Hill International Edition.

Mallick, E., Rabindra, K. P., Hare, R. T., \& Lalatendu, K. J. (2015). Organizational citizenship behavior, job performance and HR practices: A relational perspective. Management and Labour Studies, 39(4), 142-158.

Organ, D. W., Podsakoff, P. M, \& MacKenzie, S. B. (2006). Organizational citizenship Behavior: Its Nature, Antecedents and Consequencesn ( $1^{\text {st }}$ ed.). London: SAGE Publications, Thousand Oaks.

Padayachee, N. K. D. (2009). The application and relevance of spiritual leadership in the JSE top 40 companies (Doctoral dissertation, The University of Pretoria, Gordon institute of Business Science, Africa). Retrieved from https://repository.up.ac.za/handle/2263/24431.

Podsakoff, N. P., Whiting, S. W., Podsakoff, P. M., \& Blume, B. D. (2009). Individual and organizational level consequences of organizational citizenship behaviors: A metaanalysis. Journal Applied Psychology, 94(1), 122-141. 
Podsakoff, P. M., Ahearne, \& MacKenzie. (2006). Transformational leader behaviours and their effect on followers' trust in leader, satisfaction and OCB. Leadership Quarterly, 1(2), 107-142.

Podsakoff, P. M., MacKenzie, Paine, J., \& Bacharach, D. (2000). Organizational citizenship behaviours: A critical review of the theoretical and empirical literature and suggestions for future research. Journal of Management, 26(3), 513-563.

Robbins, S. P., \& Timothy, J. A. (2011). Organizational Behavior (Fourteenth). New Jersey: Pearson Education.

Saadiah, H., Mohamad, B., \& Hayaati, S. (2014). The role of integrity as a mediator between work satisfaction and work performance in the perspective of Islam: An empirical Approach using SEM/AMOS Model. International Journal of Research in Applied, Natural and Social Sciences, 2(1), 71-84.

Saleem, H. (2015). The impact of leadership styles on job satisfaction and mediating role of perceived organizational politics. Procedia - Social and Behavioral Sciences, 172(2015), 563-569.

Salehi, M., \& Goltash, A. (2011). The relationship between job satisfaction, job burnout, and organizational commitment with organizational citizenship behavior among members of faculty in the Islamic Azad University-first district branches, in order to provide the appropriate model. Procedia Social and Behavioral Sciences, 15(2011), 306-310.

Sani, A., Ekowati, V. M., Wekke, I. S., \& Idris, I. (2018). Respective contribution of entrepreneurial leadership through organizational citizenship behaviour in creating employee's performance. Academy Of Entrepreneurship Journal, 24(4), 1-11.

Sani, A., \& Ekowati, V.M. (2019). Spirituality at work and organizational commitment as moderating variables in relationship between Islamic spirituality and OCB IP and influence toward employee performance. Journal of Islamic Marketing. https://doi.org/10.1108/JIMA-08-2018-0140

Sani, A., Soetjipto, B. E., \& Maharani, V. (2016). The effect of spiritual leadership on workplace spirituality, job satisfaction and ihsan behaviour (a study on nurses of Aisyiah Islamic Hospital in Malang, Indonesia). International Journal of Applied Business and Economic Research, 14(11), 7675-7688.

Solimun, \& Fernandes, A. A. R. (2017). Investigate the instrument validity consistency between criterion validity and unidimensional validity (case study in management research. International Journal of Law and Management, 59(6), 1-10. https://doi.org/10.1108/IJLMA-09-2016-0076.

Stamper, C. L., \& Dyne, V. L. (2001). Work status and organizational citizenship behavior : A field study of restaurant employees. Journal of Organizational Behavior, 22(5), 517-36.

Ugboro, I. O. \& Obeng, K. (2000). Top management leadership, employee empowerment, job satisfaction, and customer satisfaction in TQM organizations: an empirical study. Journal of Quality Management, 5(2), 247-272.

Wijayanti, R., \& Wajdi, F. (2012). Pengaruh kepemimpinan islami, motivasi dan kepuasan kerja terhadap kinerja karyawan dengan lama kerja sebagai variabel moderating. DAYA SAING Jurnal Ekonomi Manajemen Sumber Daya, 13(2), 108-115.

Yusof, J. M., \& Tahir, I. M. (2011). Spirituality leadership and job satisfaction. A proposed conceptual framework. Information Management and business review, 2(6), 239-245. 